\title{
Comparison of World Trade Center dust with zinc acetate and lead oxide combinations to determine damage to human lung cells
}

\author{
Niharika Pattnaik* and Ann Marie DiLorenzo
}

Department of Biology and Molecular Biology, Montclair State University, Montclair, NJ 07043, United States of America.

Accepted 5 March, 2013

\begin{abstract}
The exposures of the World Trade Center (WTC) dust of the September 11, 2001 tragedy are linked to increased respiratory problems and emergence of World Trade Center Cough. Zinc $(\mathrm{Zn})$ and Lead $(\mathrm{Pb})$ are among the many heavy metals found in WTC dust. Synergistic effects among several chemicals might be contributing to respiratory illness. The individual toxicity, and combination treatments of $\mathrm{Pb}$ and $\mathrm{Zn}$ at a particular ratio of concentration (1:10) typical to Market Streets were carried out on MRC-5 human lung cells. Cells were treated as both physiologically stressed (2.5\% Fetal bovine serum, \{FBS\}) and unstressed (10\% FBS) condition in vitro. Triplex assays indicated that $\mathrm{Pb}$ and $\mathrm{Zn}$ do show antagonistic effects with each other. The combination treatments of both $\mathrm{Pb}$ and $\mathrm{Zn}$ reduced high individual toxicity of either alone, in both stressed and unstressed cells. In summary, $\mathrm{Pb}$, which is known to be highly damaging to human lung cells is modified by the presence of $\mathrm{Zn}$. It can be possible that $\mathrm{Zn}$ is a reward in disguise to WTC victims. Without unusual levels of $\mathrm{Zn}, \mathrm{Pb}$ might be much more damaging to those exposed to WTC dust.
\end{abstract}

Key words: World Trade Center, toxicity, synergistic, antagonistic, stressed cell, unstressed cell, heavy metals.

\section{INTRODUCTION}

The explosion and collapse of the World Trade Center (WTC) produced an aerosol plume affecting many workers, residents, and commuters. The inorganic analyses of three bulk samples indicated high amount of metals, ionic species, and asbestos. The organic analyses implied polycyclic aromatic hydrocarbons (PAHs), polychlorinated biphenyls, polychlorinated ibenzodioxins, pesticides, phthalate esters, brominated diphenyl ethers, and other hydrocarbons. The morphological analyses of the mass were fibrous, consisting of mineral wool, fiberglass, asbestos, wood, paper, and cotton (Lioy et al., 2002). The very high levels of exposure are linked to increased cardiovascular deaths, respiratory problems, and emergence of WTC cough.
"WTC cough" first emerged within $24 \mathrm{~h}$ after the buildings collapsed. Rescue workers showed symptoms which resulted in the diagnosis of Reactive airway dysfunction syndrome (RADS) that includes wheezing, difficulty breathing, bronchial constriction, reduced lung volume capacity, as well as possible abnormalities in the morphology of cells lining the air passages (Greenberger, 2008). Though research is ongoing, processes responsible for decreased lung function have not yet been understood on a cellular level. It has been found that workers and residents within a 1 mile radius of the WTC site are still affected by lower respiratory symptoms (Lin et al., 2010). The most recent study indicated that for average forced expiratory volume (FEV) decreased significantly 
significantly without recovery over a six year period (Aldrich et al., 2010).

Asthma prevalence among children less than 5 years of age was higher than National estimates, and new asthma diagnosis was associated with dust cloud exposure in all age groups of children (Thomas et al., 2010). WTC dust (at least the super coarse particle fraction) or cigarette smoke extract (CSE) alone has been demonstrated to direct adverse effects on airway epithelial and smooth muscle cells.

In addition, the combination of CSE and very small sized particulate matter from WTC exerted an interactive effect on cell toxicity (Xu et al., 2011). Studies of the exposure to WTC dust led to decreased cell proliferation and increased apoptosis levels in cell grown in vitro (Lambroussis et al., 2009). The components that make up the dust may have an additive effect, even if the components on their own are non reactive or non-toxic. One toxicological profile when combined with another can alter the properties of the original, making the combined profile more toxic than the individual effects alone (Donaldson et al., 1998; Ferin, 1994).

Occupational inhalation exposures to heavy metals are associated with lung cancers (Fatur et al., 2003). Materials within the WTC dust included lead, asbestos, glass, as well as numerous aromatic ring compounds (Greenberger, 2008). The International Agency for Research on Cancer (IARC) classified $\mathrm{Pb}$ as possible human carcinogen (group 2B) (IARC, 1987) and inorganic $\mathrm{Pb}$ compounds as probable human carcinogens (group 2A) (IARC, 2006). The WTC dust contains Pb that was produced from the electrical wiring, power cords, plumbing and general building material. About 50,000 personal computers were destroyed, with each containing approximately 4 pounds of $\mathrm{Pb}$ (Nordgrén et al., 2002). There has been found 1 to $3 \mathrm{~g} / \mathrm{kg}$ of $\mathrm{Zn}$ present in WTC dust, and the concentration of $\mathrm{Zn}$ exceeds 1,000 ppm in all dust collections. The trace amount would normally be considered less than $10 \mathrm{ppm}$ (Tahil, 2006).

The respiratory system is a direct target of possible environmental carcinogens (Klein-Szanto et al., 1982). It is important that the metal ions should be maintained within strict limits to maintain human health (Bertini and Cavallaro, 2008). It has been proposed that $\mathrm{Zn}$ acts as an antioxidant and a chelator agent in lead toxicity (Dykeman et al., 2002; Lidsky and Schneider, 2003; Huang and Schneider, 2004; Shalan et al., 2005; Bellinger, 2006). Zinc co-administration might alleviate toxic effects of $\mathrm{Pb}$ on the male reproductive system, whereas it could enhance the toxicity on thyroid function. Divalent $\mathrm{Pb}$ and $\mathrm{Zn}$ have similar chemical properties and it is possible that $\mathrm{Pb}$ can influence the absorption and distribution of $\mathrm{Zn}$ in blood and other tissue. The doubleedged effects of $\mathrm{Zn}$ on $\mathrm{Pb}$ toxicity on different organ systems should be evaluated. The protective effect of $\mathrm{Zn}$ on reproductive toxicity of $\mathrm{Pb}$ may be attributed to competition between $\mathrm{Pb}$ and $\mathrm{Zn}$, or reduction of available
$\mathrm{Pb}$-binding sites in the testicular tissue (Fengyuan et al., 2007).

There is a power relationship between $\mathrm{Pb}$ and $\mathrm{Zn}$ in WTC dust. Also, in almost all WTC sample collected, the ratio of $\mathrm{Pb}$ and $\mathrm{Zn}$ varies from 1:7 to $1: 12$. In the market street samples, the ratio of concentration between $\mathrm{Pb}$ and $\mathrm{Zn}$ is around $1: 10$ (Tahil, 2006). In this study, $\mathrm{Zn}$ and $\mathrm{Pb}$ are used in ratios found in WTC dust. These heavy metals alone, and in conjunction with WTC dust, become indicators of damage to human lung cells shown by changes in cytotoxicity.

\section{MATERIALS AND METHODS}

MRC- 5 human lung fibroblast cells were obtained from American Type Culture Collection. Cells lines were initially grown in Eagles Minimum Essential Medium (MEM) that had been supplemented with $1 \mathrm{ml}$ of Penicillin-streptomycin, $1 \mathrm{ml}$ of glutamine, $1 \mathrm{ml}$ of kanamycin and $10 \mathrm{ml}$ Fetal Bovine Serum (FBS) per $100 \mathrm{ml}$ of media. The experiments utilized stressed MRC-5 cells that were exposed to $2.5 \%$ FBS and unstressed MRC-5 cells that were grown in $10 \%$ FBS. This study used lower percentages of FBS in the media to simulate the effects of physiological stress on the cells. Cells were allowed to grow to a confluent monolayer until needed.

Zinc acetate $\left\{\mathrm{Zn}\left(\mathrm{O}_{2} \mathrm{CCH}_{3}\right)_{2}\right\}$ and Lead oxide $(\mathrm{PbO})$ were used in these experiments, as these were completely soluble in media. One $(1 \mathrm{~g}) \mathrm{PbO}$ was dissolved in $100 \mathrm{ml}$ of complete medium with 10 and $2.5 \%$ FBS, respectively. These solutions represent $10,000 \mathrm{ppm}$ stock solution for $\mathrm{PbO}$ for both stressed and unstressed conditions. Appropriate dilutions were performed to make 1, 50, 100,300, and $500 \mathrm{ppm}$. Similar procedure was followed to prepare $10,000 \mathrm{ppm}$ stock solution of $\left\{\mathrm{Zn}\left(\mathrm{O}_{2} \mathrm{CCH}_{3}\right)_{2}\right\}$, and $10,100,500,1000$, and 3000 ppm solutions for zinc acetate in both 10 and $2.5 \%$ FBS were prepared. All the procedures were carried out aseptically.

The combination treatments for the experiments are the combination of $\mathrm{Pb}$ and $\mathrm{Zn}$ in specific ratio $(1: 1,1: 5,1: 10$ and $1: 15)$ of their concentration in 10 and $2.5 \%$ FBS in complete medium. All ratios were followed to comply with the ratios of these heavy metals found in the analyzed dust from the WTC (Lioy et al., 2002). The preparation of the required combinations followed those shown in Table 1.

To prepare for assays, MRC-5 cell cultures were scraped, centrifuged, and seeded in fresh complete medium containing $10 \%$ FBS. A $100 \mu \mathrm{l}$ of cells were plated into 3 black $300 \mu \mathrm{l} 96$-well clear flat bottom plates and incubated for $24 \mathrm{~h}$ at $37^{\circ} \mathrm{C}$. After a $24 \mathrm{~h}$ incubation period, the old media was aseptically removed and various solutions of $\left\{\mathrm{Zn}\left(\mathrm{O}_{2} \mathrm{CCH}_{3}\right)_{2}\right\}, \mathrm{PbO}$ and combination of $\left\{\mathrm{Zn}\left(\mathrm{O}_{2} \mathrm{CCH}_{3}\right)_{2}\right\}$ and $\mathrm{PbO}$ solution were put in the designated well. In all assays performed in this type of 96-well plates, two wells with media were used for negative control.

The toxicity level of $\mathrm{Zn}, \mathrm{Pb}$ and their interaction were analyzed by using ApoTox-Glo Triplex Assay obtained from Promega, Inc. Fluorescence was measured at $485 \mathrm{~nm}$ emission and $528 \mathrm{~nm}$ excitation to determine cytotoxicty, using a Bio-Tech Synergy 2 multi plate reader.

\section{Statistical analysis}

All data are expressed as mean \pm standard deviation (SD). For statistical analyses, One-way Analysis of variance (ANOVA) with Student Newman Keul post-hoc analysis was used to determine significant difference between exposure and control. 
Table 1. Different concentrations and volume of $\mathrm{PbO}$ and $\left\{\mathrm{Zn}\left(\mathrm{O}_{2} \mathrm{CCH}_{3}\right)_{2}\right\}$ taken to prepare required WTC dust ratios of combination.

\begin{tabular}{|c|c|c|c|c|c|c|}
\hline $\begin{array}{c}\text { Ratio of } \\
\mathrm{PbO} /\left\{\mathrm{Zn}\left(\mathrm{O}_{2} \mathrm{CCH}_{3}\right)_{2}\right\}\end{array}$ & $\begin{array}{c}\text { Concentration of } \\
\mathrm{PbO}(\mathrm{ppm})\end{array}$ & $\begin{array}{c}\text { Concentration of } \\
\left\{\mathrm{Zn}\left(\mathrm{O}_{2} \mathrm{CCH}_{3}\right)_{2}\right\} \text { (ppm) }\end{array}$ & $\begin{array}{l}\text { Volume of } \\
\mathrm{PbO}(\mu \mathrm{l})\end{array}$ & $\begin{array}{c}\text { Volume of } \\
\left\{\mathrm{Zn}\left(\mathrm{O}_{2} \mathrm{CCH}_{3}\right)_{2}\right\}(\mu \mathrm{l})\end{array}$ & $\begin{array}{c}\text { Final concentration } \\
\text { of } \mathrm{PbO}(\mathrm{ppm})\end{array}$ & $\begin{array}{c}\text { Final Concentration of } \\
\left\{\mathrm{Zn}\left(\mathrm{O}_{2} \mathrm{CCH}_{3}\right)_{2}\right\}(\mathrm{ppm})\end{array}$ \\
\hline $1: 1$ & 100 & 100 & 50 & 50 & 50 & 50 \\
\hline $1: 5$ & 200 & 1000 & 50 & 50 & 100 & 500 \\
\hline $1: 10$ & 100 & 1000 & 50 & 50 & 50 & 500 \\
\hline $1: 15$ & 200 & 3000 & 50 & 50 & 100 & 1500 \\
\hline
\end{tabular}

\section{RESULTS}

\section{Cytotoxicity of combination treatment}

Toxicity of cells stressed by reduction in serum level is consistently higher than unstressed cells. This is visualized in Figures 2, 3a and b. The combination treatment of $1: 10$ ratio of $\mathrm{Pb}$ and $\mathrm{Zn}$ represent the established market street $\mathrm{Pb}$ and $\mathrm{Zn}$ ratio for these heavy metals (Lioy, 2002).

The analysis of Figure 5 indicates that $\mathrm{Pb}$ at 50 ppm and $\mathrm{Zn}$ at $500 \mathrm{ppm}$ generate an expected high toxicity in unstressed condition. Combination of these two treatments producing a ratio of their concentration of $(1: 10)$ create a toxicity considerably lower as compared to individual toxicity of $\mathrm{Pb}$ or $\mathrm{Zn}$. Combination treatments were able to reduce the high amount of toxicity produced by $\mathrm{Pb}$ in unstressed condition. Figure 4 demonstrates that the combination treatments of $\mathrm{Pb}$ and $\mathrm{Zn}$ produce a toxicity which is very low in comparison to the individual toxicity of $\mathrm{Pb}$ and $\mathrm{Zn}$ in stressed condition. Thus, combination treatment is able to reduce the individual toxicity of $\mathrm{Pb}$ or $\mathrm{Zn}$ in stressed condition.

\section{DISCUSSION}

The results of these experiments have shown that toxicity is always highest in cells stressed by serum level reduction. Surprisingly, the high amount of $\mathrm{Zn}$ reduced the damaging effects of $\mathrm{Pb}$ both in stressed and unstressed cell. It indicates $\mathrm{Zn}$ and $\mathrm{Pb}$ appear to show some antagonistic interaction with each other in human lungs cells in vitro. The issue of chemical additivity and synergism is particularly important in regards to the unique mixture created by the unprecedented circumstances of the WTC event (Goad et al. 2004). Chemicals are said to exert an antagonistic effect when combination of both metals have an overall effect that is less than the sum of their individual effects (Peyrat-Maillard et al., 2003). From Figures 4 and 5 , it is seen that $\mathrm{Zn}$ administration could reduce $92 \%$ of $\mathrm{Pb}$ toxicity in unstressed condition whereas it could reduce $72 \%$ of $\mathrm{Pb}$ toxicity in stressed condition.

By comparing Figures 4 and 5, it can be concluded that antagonistic effects of $\mathrm{Zn}$ and $\mathrm{Pb}$ is lower in stressed cell in comparison with unstressed cells. It can be concluded that $\mathrm{Pb}$ and $\mathrm{Zn}$ had antagonistic effects which reduced the high amount of individual toxicity of $\mathrm{Pb}$ or $\mathrm{Zn}$ both in stressed and unstressed condition. Divalent $\mathrm{Pb}$ and $\mathrm{Zn}$ have similar chemical properties and it is possible that $\mathrm{Pb}$ can influence the absorption and distribution of $\mathrm{Zn}$ in blood and other tissue by interfering with the transport system of $\mathrm{Zn}$. The previously published evidence for a protective effect of $\mathrm{Zn}$ on the reproductive toxicity of $\mathrm{Pb}$ may be attributed to competition between $\mathrm{Pb}$ and $\mathrm{Zn}$, or reduction of available $\mathrm{Pb}$-binding sites in the testicular tissue (Fengyuan et al., 2007).

Additional investigations should be continued to study the cytotoxicity of $\mathrm{Zn}$ in unstressed and stressed condition. The in vitro stressed conditions brought on by serum lowering or deprivation, are a representation of the actual physiological stress conditions of some of the individuals exposed to the particulate matter of the WTC tragedy. Zinc, in the form of zinc acetate, is highly basic and needs an acidic environment to dissolve. Even if concentration is very high, it may not be dissolved in lung cells enough to demonstrate its toxicity. Thus, toxicity of $\mathrm{Zn}$ should be tested in other cells such as nerve cells and stomach cells. Stomach acid contains hydrochloric acid, in which metallic zinc dissolves readily to give corrosive zinc chloride (Bothwell et al., 2003).

Comparing the graphs of Figures 2, 3a and b, it is concluded that the toxicity in stressed cells is at considerably higher levels than unstressed cells. In Figure 2, $\mathrm{Pb}$ has higher toxicity in all the treatment in stressed cell than unstressed cell. Comparing the graphs of Figure $3 a$ and $b$, it is seen that the toxicity of stressed cell is unpredictably higher than the unstressed cell in all the treatments, including $1: 5,1: 10$ and $1: 15$ ratios of treatment. The ratio of 1:10 $(\mathrm{Pb}: \mathrm{Zn})$ represents market street $\mathrm{Pb}$ and $\mathrm{Zn}$ ratio, and the toxicity of stressed cell is $40.79 \%$ higher than toxicity of unstressed cell. This amount of increased toxicity of 


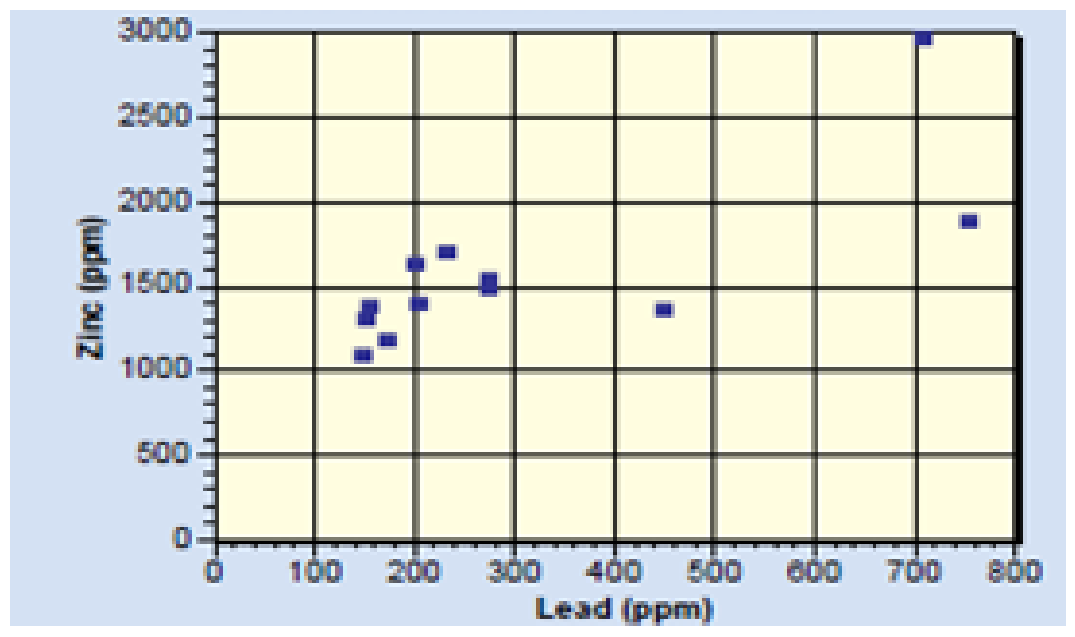

Figure 1. The ratio of concentration of $\mathrm{Pb}$ and $\mathrm{Zn}$ in WTC; not including Girder Coating Samples (Tahil, 2006).

It shows that the ratios of $\mathrm{Pb}$ to $\mathrm{Zn}$ in every collected sample are between $1: 7$ and 1:12.

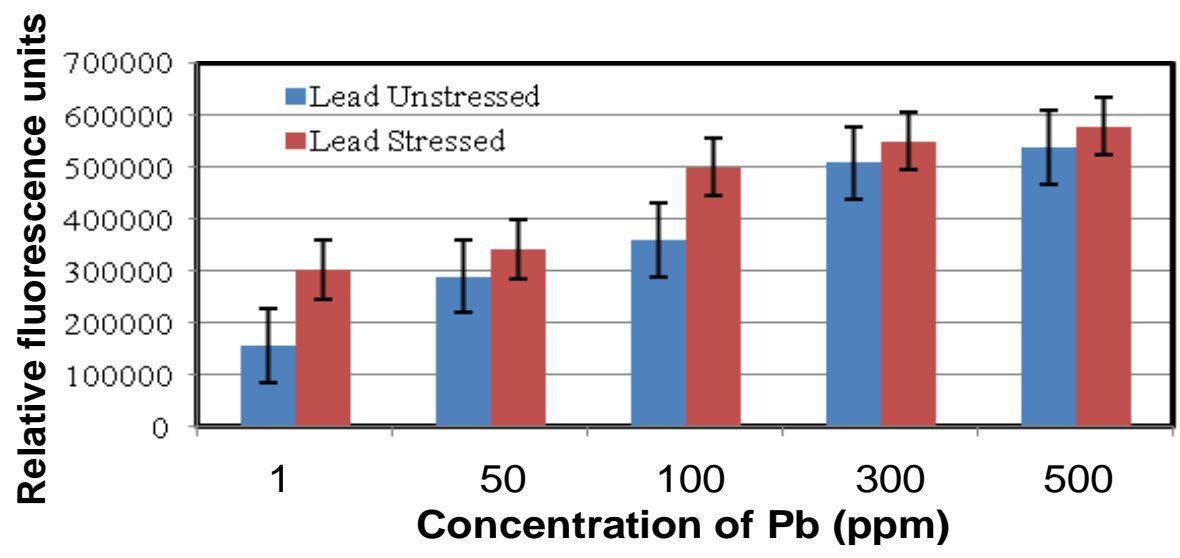

Figure 2. Cytotoxicity of $\mathrm{Pb}$ in unstressed and stressed condition. The toxicity increases as the concentration of $\mathrm{Pb}$ increases.

stressed cell is unpredictably high.

Figure 1 indicates the $\mathrm{Pb}$ and $\mathrm{Zn}$ ratio of WTC which is in between $1: 7$ and 1:12. It is predicted that in the areas of WTC containing these ratios, there must have been considerably higher toxicity in stressed cell than unstressed cell. Higher concentrations of FBS provide cells with a variety of proteins needed for survival and growth. The cells exposed to $10 \%$ FBS have access to higher levels of proteins that allow for optimal growth. Cells grown in $2.5 \%$ FBS are grown in more physiological stressful environments than cells grown in $10 \%$ FBS. The increase in toxicity noted in cells grown in lower FBS concentrations indicate that lower concentrations of FBS show a possible negative impact on cell growth at the various concentrations and ratios of $\mathrm{Pb}$ and/or $\mathrm{Zn}$. This data implies that a person having lower resistance due to mental or physiological stress might actually be more susceptible to toxicity and cellular damage.

\section{CONCLUSION AND RECOMMENDATION}

The repeated experimental uses of assays to measure cytotoxicity demonstrate that $\mathrm{Pb}$ is capable of damage to cultured human lung cells in both stressed and unstressed condition. This study evolved out of a concern for the potential long-term lung problems faced by victims of exposure to the dust and other particulate matter from the WTC tragedy. Our research demonstrated that the high level of Zn, contrary to our expectation, displays an antagonistic effect with $\mathrm{Pb}$ which reduced the highly toxic effects of $\mathrm{Pb}$. The very high concentration of $\mathrm{Zn}$, ranging 


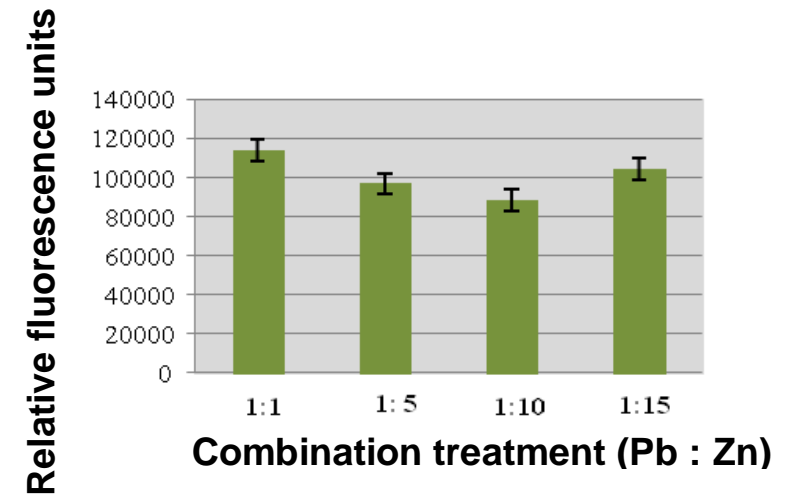

(a)

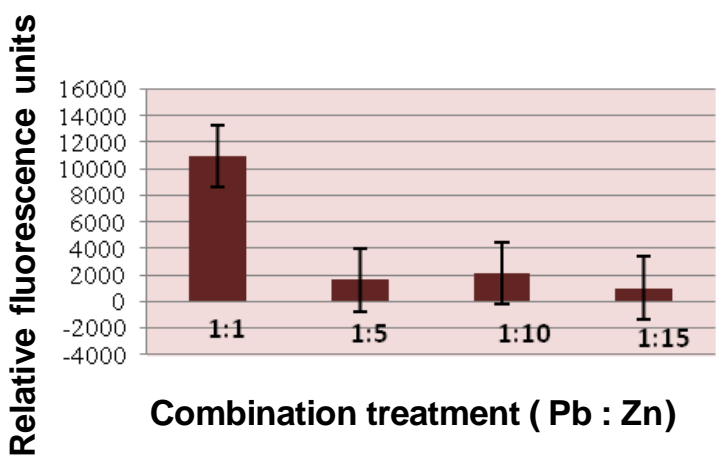

(b)

Figure 3. Graphs showing cytotoxicity of combination treatment of different ratio of $\mathrm{Pb}: \mathrm{Zn}$ in (a) stressed and (b) unstressed condition. The $\mathrm{Pb}: \mathrm{Zn}$ ratio of market street dust as 1:10.

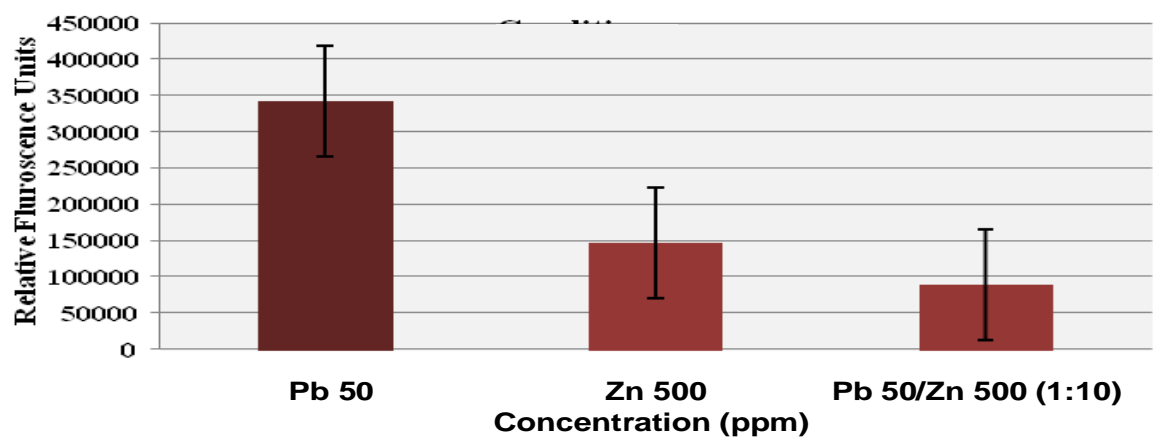

Figure 4. Comparison of individual toxicity of $\mathrm{Pb}$ and $\mathrm{Zn}$ with combination toxicity of $\mathrm{Pb}$ and $\mathrm{Zn}$ at 1:10 ratio in stressed condition. The graph shows that individual toxicity of $\mathrm{Pb}$ at $50 \mathrm{ppm}$ is 342069.5 Relative Fluorescence Units (RFU) and individual toxicity of Zn at $500 \mathrm{ppm}$ is 146372.5 RFU. Combination treatment of $\mathrm{Pb}$ at $50 \mathrm{ppm}$ and $\mathrm{Zn}$ at $500 \mathrm{ppm}$ gives a toxicity of 88383.5 RFU.

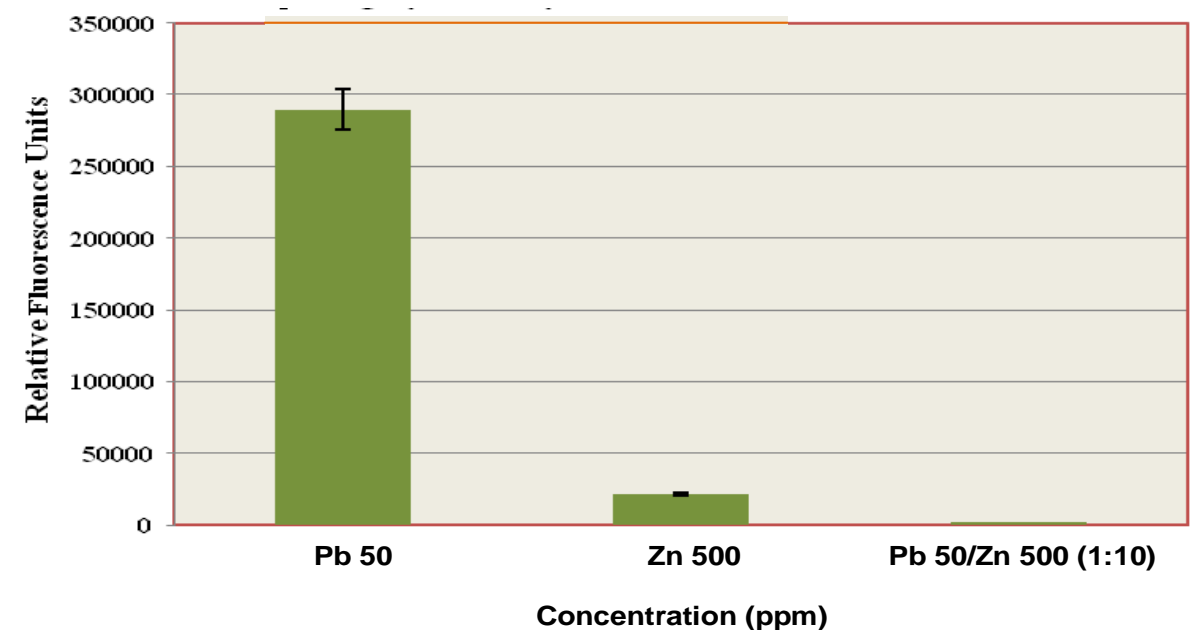

Figure 5. Comparison of individual toxicity of $\mathrm{Pb}$ and $\mathrm{Zn}$ with combination toxicity of $\mathrm{Pb}$ and $\mathrm{Zn}$ at 1:10 ratio of both metal's concentrations in unstressed condition. Graph shows that individual toxicity of $\mathrm{Pb}$ at $50 \mathrm{ppm}$ is 289,690 Relative Fluorescence Units (RFU) and individual toxicity of $\mathrm{Zn}$ at $500 \mathrm{ppm}$ is $21,144.5 \mathrm{RFU}$. Combination treatment of $\mathrm{Pb}$ at 50 ppm and $Z n$ at 500 ppm gives a toxicity of 2117.5 RFU. 
from 1,000 to $3,000 \mathrm{ppm}$, is a "reward in disguise" to WTC victims, without which $\mathrm{Pb}$ could be much more damaging. The toxicity of $\mathrm{Pb}$ may not be damaging to healthy people because of the protective role of $\mathrm{Zn}$ but it can be troublesome to infants, diseased, sick, old and those with low resistance due to stress. Though more research is needed to properly identify the potential risk of heavy metals from the WTC dust, the results in this study suggest that $\mathrm{Pb}$ is more damaging to low resistant people, and the protective role of $\mathrm{Zn}$ may be able to hide the damaging effect of $\mathrm{Pb}$ to normal healthy people.

Additive and synergistic effects on toxicity are possible from the interaction of other hazardous substances found in the WTC dust. Synergistic and additive effects can occur with asbestos, PAHs and polychlorinated biphenyls (PCBs), with particulate matter and $\mathrm{PAHs}$, with $\mathrm{Pb}$ and $\mathrm{Hg}$ (mercury), and also with dioxin and PCBs (Goad et al., 2004). Future research should be carried out for possible interaction between $\mathrm{Pb}$ and mercury. The individual toxicity, viability, and apoptosis experiments of $\mathrm{Zn}$ should be designed to study effects in both stressed and unstressed condition. In addition to lung cells, neuronal cells and in particular, stomach cells, should be tested to demonstrate the possible toxicity levels of $\mathrm{Zn}$ in these organs.

\section{REFERENCES}

Aldrich TK, Gustave J, Hall CB, Cohen HW, Webber MP, Zeig-Owens R, Cosenza K, Christodoulou V, Glass L, Al-Othman F, Weiden MD, Kelly KJ, Prezant DJ (2010). Lung function in rescue workers at the World Trade Center after 7 years. N. Engl. J. Med. 362(14):12631272.

Bellinger DC (2006). Lead. Pediatrics 113:1016 -1022.

Bertini I, Cavallaro G (2008). Metals in the "omics" world: copper homeostasis and cytochrome $c$ oxidase assembly in a new light. J. Biol. Inorg. Chem. 13 (1):3-14.

Bothwell DN, Mair EA, Cable BB (2003). Chronic Ingestion of a ZincBased penny. Pediatrics 111(3):689-691.

Donaldson K, Li XY, MacNee W (1998). Ultrafine (nanometer) particlemediated lung injury. J. Aerosol Sci. 29:553-560.

Dykeman R, Aguilar-Madrid G, Smith T, Juarez-Perez CA, Piacetelli GM, Hu H, Hernandez-Avila M (2002). Lead exposure in Mexican radiator repair workers. Am. J. Ind. Med. 41:179-187.

Fatur T, Lah TT, Filipic M (2003). Cadmium inhibits repair of UV- methyl methanesulfonate-and N-methyl-N-nitrosourea-induced DNA damage in Chinese hamster ovary cells. Mutat. Res. 529(1-2):109-116.

Fengyuan P, Fanyin C, Haibo C, Gang LI, Xiance S, Shuang L, Toru Y, Kazuhito $Y$ (2007). Effect of Zinc co-administration on lead toxicity of Rats. Ind. Health 45:546-551.

Ferin J (1994). Pulmonary retention and clearance of particles. Toxicol. Lett. 72(1-3):121- 5.

Greenberger PA (2008). Immunologic lung disease. J. Allerg. Clin. Immunol. 121:393-397.

Goud PT, Nye AC, Washburn SC, Jarvis JQ, Blume RS, Gunter BJ (2004). Risk assessment and public health implication of WTC Dust Contamination of the Deutsche Bank 130 Liberty Street Property. Deutsche Bank.
Huang F, Schneider JS (2004). Effects of lead exposure on proliferation and differentiation of neural stem cells derived from different regions of embryonic rat brain. Neurotoxicology 25:1001-1012.

IARC (International Agency for Research on Cancer) (2006). Inorganic and organic lead compounds. IARC monographs on the evaluation of carcinogenic risks to humans. Lyon, France. Volume 87, pp. 1-471.

IARC (International Agency for Research on Cancer). (1987). Lead and lead compounds. In: Overall Evaluations of Carcinogenicity. IARC Monographs on the Evaluation of Carcinogenic Risk of Chemicals to Humans. International Agency for Research on Cancer. Lyon, France. Suppl 7, pp. 230-232.

Klein-Szanto AJ, Terzaghi M, Mirkin LD, Martin D, Shiba M (1982, Aug). Propagation of normal human epithelial cell populations using an in vivo culture system: Description and applications. Am. J. Pathol.. 108(2):231-239.

Lambroussis CG, Soares BD, Perez S, Gaipa D, Elie AL, Ament CM, Rouf FT, Bassa LM, DiLorenzo AM (2009). Indications of Potential Toxic/Mutagenic Effects of World Trade Center Dust on Human Lung Cell Cultures. Online J. Biol. Sci. 9:81-85.

Lidsky TI, Schneidser JS (2003, January). Lead neurotoxicity in children: basic mechanisms and clinical correlates. Brain 126:5-19.

Lin S, Jones R, Reibman J, Morse D (2010). Lower respiratory symptoms among residents living near the World Trade Center, two and four years after 9/11. International J. Occup. Environ. Health 16(1):44-52.

Lioy PJ, Weisel CP, Millette JR, Eisenreich S, Vallero D, Offenberg J, Buckley B, Turpin B, Zhong M, Cohen MD, Prophete C, Yang, Stiles R, Chee G, Johnson W, Porcja R, Alimokhtari S, Hale RC, Weschler C, Chen LC (2002). Characterization of the dust/smoke aerosol that settled east of the World Trade Center (WTC) in lower Manhattan after the collapse of the WTC 11 September 2001. Environ. Health Perspect. 110:703-714.

Nordgrén MD, Goldstein EA, Izeman MA (2002, February). The Environmental Impacts of the World Trade Center Attacks. A Preliminary Assessment. Natural Resources Defense Council (NRDC). Retrieved July 20, 2012 from www.nrdc.org/air/pollution/wtc/wtc.pdf

Peyrat-Maillard MN, Cuvelier ME, Berset C (2003). Antioxidant activity of phenolic compounds in 2,2'-azobis (2-amidinopropane) dihydrochloride (AAPH)- induced oxidation: Synergistic and antagonistic effects. J. Am. Oil Chem. Soc. 80(10):1007-1012.

Promega Corporation (2011). ApoTox-Glo ${ }^{\mathrm{TM}}$. Triplex Assay Technical Bulletin \#TM322.

Shalan MG, Mostafa MS, Hassouna MM, El-Nabi SE, El-Refaie A (2005). Amelioration of lead toxicity on rat liver with Vitamin C and silymarin supplements. Toxicology 206(1):1-15.

Tahil W (2006). Ground Zero: The Nuclear Demolition of World Trade Center. Retrieved July 20, 2012 from: www.nucleardemolition.com/GZero_Sample.pdf.

Thomas PA, Brackbill R, Thalji L, DiGrande L, Campolucci S, Thorpe L, Henning K (2008). Respiratory and other health effects reported in children exposed to the World Trade Center disaster of 11 September 2001. Environ. Health Perspect. 116(10):1383-90.

Xu A, Prophete C, Chen LC, Emala CW, Cohen MD (2011). Interactive effect of cigarette smoke extract and world trade center dust particles on airway cell cytotoxicity. J. Toxicol. Environ. Health A. 74(14):887902. 